\title{
Diversity, distribution and taxonomy of Cladosporium associated with Celastraceae
}

\author{
Bhartiya $\mathrm{HD}^{1}$, Kumari $\mathrm{N}^{2}$, Kumar $\mathrm{S}^{3^{*}}$ and Singh $\mathrm{R}^{4}$
}

${ }^{1}$ Department of Botany, Bipin Bihari Post Graduate College, Jhansi - 284001 (U.P.), India.

${ }^{2}$ Department of Botany, D.D.U. Gorakhpur University, Gorakhpur - 273009 (U.P.), India.

${ }^{3}$ Department of Forest Pathology, Kerala Forest Research Institute, Peechi - 680653 (Kerala), India.

${ }^{4}$ Centre of Advanced Study in Botany, Institute of Science, Banaras Hindu University, Varanasi- 221005 (U.P.), India.

Bhartiya HD, Kumari N, Kumar S, Singh R 2016 - Diversity, distribution and taxonomy of Cladosporium associated with Celastraceae. Plant Pathology \& Quarantine 6(1), 48-52, Doi $10.5943 / \mathrm{ppq} / 6 / 1 / 7$

\begin{abstract}
Cladosporium hippocrateae sp. nov., discovered on living leaves of Hippocratea arborea (Celastraceae) collected from subtropical forest region of Uttar Pradesh, India is described and illustrated. The species is compared morphologically with $C$. subobtectum another species described on family Celastraceae. The novel species is characterized by branched, longer, smooth conidiophores and longer and smooth conidia. A description and nomenclatural details are deposited in MycoBank (www.MycoBank.org).
\end{abstract}

Key words - Celastraceae - Cladosporium - foliicolous hyphomycetes - mycodiversity - new species

\section{Introduction}

The fungus genus Cladosporium was established by Link (1816). A review of the history of Cladosporium has been given by David (1997). Cladosporium (incl. Heterosporium) is characterized and distinguished from other Mycosphaerella anamorphs by its unique type of conidial scars and conidial hila. Cladosporium is one of the largest and most heterogeneous genera of hyphomycetes, currently encompassing more than 772 names (Dugan et al. 2004). The species are cosmopolitan in distribution and commonly encountered in all kinds of habitat. Many of the species are plant pathogenic, i.e., they are causal agents of leaf spots and other lesions (Schubert 2005), or they occur as hyperparasites on other fungi (Heuchert et al. 2005). A monographic revision of Cladosporium s. lat. was presented by Bensch et al. (2012). They included a detailed historic overview of Cladosporium and allied genera, with notes on the phylogeny, systematics and ecology.

Many novel taxa of Cladosporium have been described from India (Bilgrami et al. 1979, 1981, 1991, Butler \& Bisby 1954, Jamaluddin et al. 2004, Sarbhoy et al. 1975, 1986, 1996). Recently some new species of Cladosporium were added to the Indian mycota from Uttar Pradesh (Kumar et al. 2006, 2007, Singh et al. 2008). During a continuing investigation on micro-fungi from the subtropical forests of Uttar Pradesh, a species with morphological characteristics of the 
genus Cladosporium was collected on leaves of Hippocratea arborea (Celastraceae). It was found to be distinct from previously described taxa and, therefore, is proposed as a new species and is described and illustrated in the present paper.

\section{Materials \& Methods}

Infected leaf samples were collected from northeastern Uttar Pradesh during the course of a field survey for inventory of foliicolous microfungi. The samples were carried to the laboratory and processed by following standard techniques (Hawskworth 1974, Savile 1962). Surface scrappings and free-hand cut sections were taken through infection spots and mounted in lactophenol cotton blue for microscopic examination. Illustrations were made using a camera-lucida. The type specimen has been deposited in Herbarium Cryptogamiae Indiae Orientalis (HCIO), Indian Agricultural Research Institute (IARI), New Delhi and an isotype in the departmental herbarium (GPU Botanical Herbarium). The morphotaxonomic determination is based on comparison with closely related taxa with the help of current literature. The systematics of the taxa is given in accordance with Cannon \& Kirk (2007), Kirk et al. (2008), and the Index Fungorum (www.indexfungorum.org; accessed 1 February 2015).

\section{Results}

\section{Taxonomy}

Cladosporium hippocrateae H.D. Bhartiya, N. Kumari, Sham. Kumar \& R. Singh, sp. nov. Fig. 1 MycoBank: 811698; Facesoffungi Number: FoF 00717

Etymology - specific epithet hippocrateae derived from the host plant genus.

Infection spots amphigenous, sub-circular to irregular, later coalescing to form large patches, blackish. Colonies amphiphyllous, effuse, greyish white. Mycelium external, hyphae branched, septate. Sexual morph: Undetermined. Asexual morph: Stromata absent. Conidiophores arising from external hyphae, single or caespitose, macronematous, mononematous, branched, smooth-walled, 0-8 septate, erect, straight or flexuous, curved, swollen, light olivaceous to olivaceous-brown, $135-335 \times 3.5-6.5 \mu \mathrm{m}$. Conidiogenous cells integrated, terminal or intercalary, polyblastic, sympodial, cicatrized, bearing thickened conidial scars. Conidia 6.5-34 × 4.5-6.5 $\mu \mathrm{m}$, dry, holoblastic, acropleurogenous, cylindrical, variable in shape and size, ellipsoidal or oval, 0-5 transversely septate, smooth-walled, apex sub-acute to obtuse, base obconico-truncate to rounded, light olivaceous, hila distinctly thickened, small but clearly protuberant.

Teleomorph - Not observed

Known distribution - India.

Material examined - India, Uttar Pradesh, Deoria, on living leaves of Hippocratea arborea Roxb. (Celastraceae), 5 December 1997, Nisha Kumari, HCIO 43144 (holotype), GPU Herb No. 8524 (isotype).

Table 1 Comparison of Cladosporium spp. reported on Celastraceae

\begin{tabular}{|c|c|c|}
\hline Species & Conidiophores & Conidia \\
\hline C. subobtectum & $\begin{array}{l}\text { Unbranched, } 20-100 \times 3- \\
6 \mu \mathrm{m} \text { smooth to distinctly } \\
\text { verruculose }\end{array}$ & $\begin{array}{l}5-28 \times 2.5-6 \\
(-8) \mu \mathrm{m}, \\
\text { verruculose }\end{array}$ \\
\hline C. hippocrateae & $\begin{array}{l}\text { Branched, } 135-365 \times 3.5- \\
6.5 \mu \mathrm{m}, \text { smooth }\end{array}$ & $\begin{array}{l}6.5-34 \times 4.5- \\
8.5 \mu \mathrm{m}, \text { smooth }\end{array}$ \\
\hline
\end{tabular}




\section{Discussion}

A survey of literature indicated that there was no record of Cladosporium on the genus Hippocratea. Cladosporium subobtectum (Braun \& Schubert 2007) was reported on Euonymus sp. of family Celastraceae from California (USA). Therefore, a comparison of morphological features was made with $C$. subobtectum. The conidiophores are unbranched, shorter $(20-100 \times 3-6 \mu \mathrm{m})$ and smooth to verruculose in $C$. subobtectum whereas those of $C$. Hippocrateae are branched, longer $(135-365 \times 3.5-6.5 \mu \mathrm{m})$ and smooth. The conidia of $C$. hippocrateae are also longer $(6.5-34 \times$ $4.5-8.5 \mu \mathrm{m})$ and smooth while those of $C$. subobtectum are shorter $(5-28 \times 2.5-6(-8) \mu \mathrm{m})$ and verruculose. Therefore, the description of $C$. hippocrateae as a new species is justified.

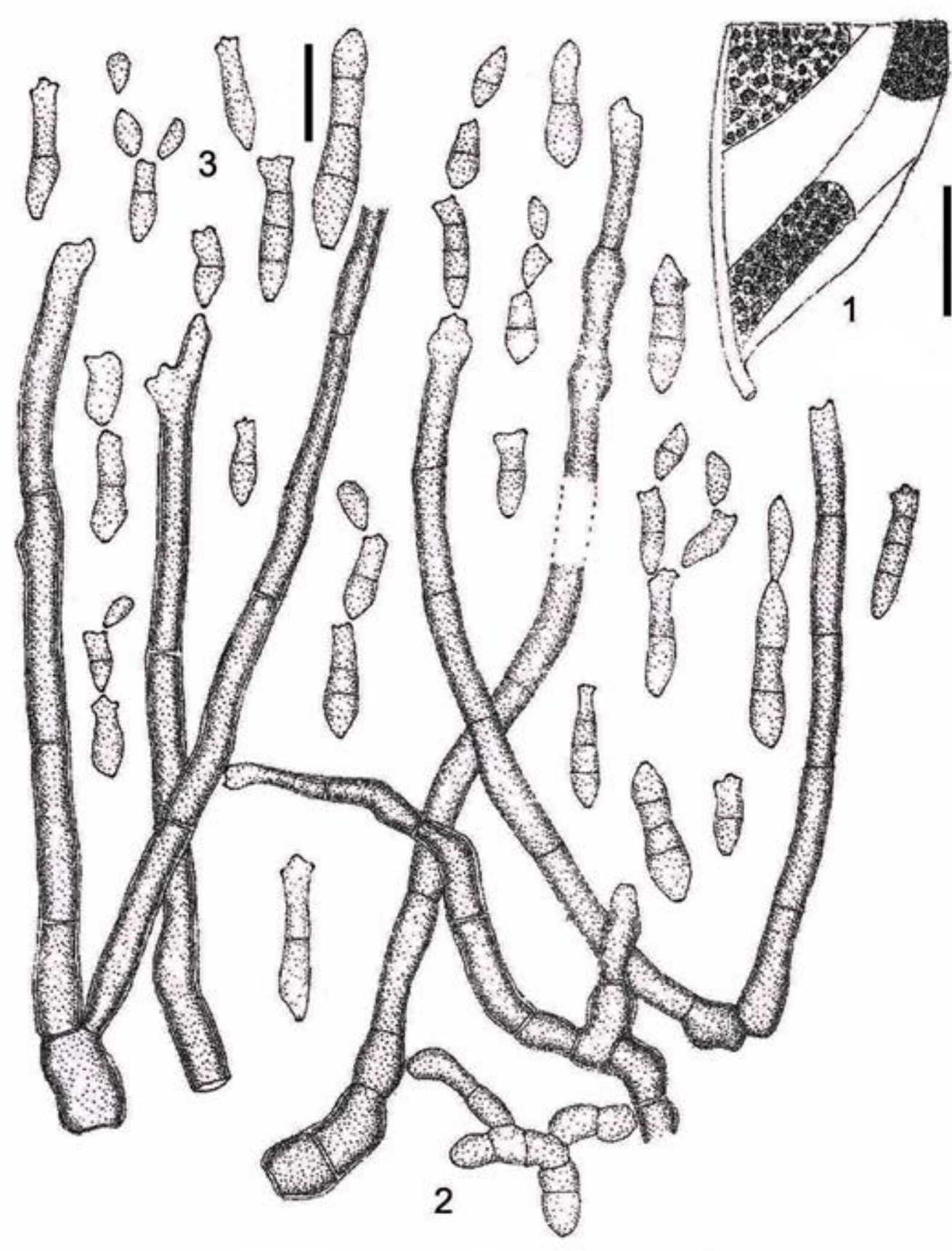

Fig. 1 - Cladosporium hippocrateae. HCIO 43144. 1 Infection spots. 2 Conidiophores. 3 Conidia. - Bars $1=20 \mathrm{~mm} .2,3=20 \mu \mathrm{m}$. 


\section{Acknowledgements}

The authors are grateful to reviewer Dr EHC McKenzie for helpful remarks on the manuscript. They express their sincere gratitude to Head, Department of Botany, DDU Gorakhpur University, Gorakhpur and Director, KFRI, Peechi, Kerala for necessary facilities. Thanks are also due to the Curator, Herbarium Cryptogamiae Indiae Orientalis (HCIO), Indian Agricultural Research Institute (IARI), New Delhi for depositing type specimens and providing accession number. Science and Engineering Research Board (SERB), Department of Science and Technology (DST), Government of India, New Delhi, is acknowledged for financial assistance to the corresponding author (SB/YS/LS-288/2013).

\section{References}

Bensch K, Braun U, Groenewald JZ, Crous PW. 2012 - The genus Cladosporium. Studies in Mycology 72, 1-401.

Bilgrami KS, Jamaluddin, Rizwi MA. 1979 - Fungi of India I. List and references. Today's and Tomorrow's Printer's and Publisher's, New Delhi. pp. 467.

Bilgrami KS, Jamaluddin, Rizwi MA. 1981 - Fungi of India II. Host Index and Addenda. Today's and Tomorrow's Printer's and Publisher's, New Delhi. pp. 128.

Bilgrami KS, Jamaluddin, Rizwi MA. 1991 - Fungi of India. List and references. Today's and Tomorrow's Printer's and Publisher's, New Delhi. pp. 798.

Braun U, Schubert K. 2007 - Taxonomic revision of the genus Cladosporium s. lat. 7. Descriptions of new species, a new combination and further new data. Schlechtendalia 16, 61-76.

Butler EJ, Bisby GR. 1954 - Fungi of India (Revised by R.S. Vasudeva). Indian Agricultural Research Institute, New Delhi. pp. 552

Cannon PF, Kirk PF. 2007 - Fungal Families of the World. Wallingford, UK, CAB International. pp. 456.

David JC. 1997 - A contribution to the systematics of Cladosporium. Revision of the fungi previously referred to Heterosporium. Mycological Papers 172, 1-157.

Dugan FM, Schubert K, Braun U. 2004 - Check-list of Cladosporium names. Schlechtendalia 11, $1-103$.

Hawskworth DL. 1974 - Mycologist's Handbook. Commonwealth Mycological Institutte, Kew, Surrey, UK.

Heuchert B, Braun U, Schubert K. 2005 - Morphotaxonomic revision of fungicolous Cladosporium species (hyphomycetes). Schlechtendalia 13, 1-78.

Index Fungorum 2015 - Index Fungorum, accessed 1 February 2015. http://www.indexfungorum. org.

Jamaluddin, Goswami MG, Ojha BM. 2004 - Fungi of India 1989-2001, Scientific Publishers, Jodhpur, India. pp. 326.

Kirk PF, Cannon PF, Minter DW, Stalpers JA. 2008 - Dictionary of the Fungi. 10th ed. Wallingford, UK, CAB International. pp. 711.

Kumar A, Kumar A, Kharwar RN. 2006 - Two new phytoparasitic hyphomycetes from Varanasi, India. Indian Phytopathology 59(1), 85-90.

Kumar S, Singh R, Pal VK, Upadhyaya PP, Agarwal DK. 2007 - Addition to new species of foliicolous hyphomycetes from North- Eastern U.P. Indian Phytopathology 60(3), 350-355.

Link HF. 1816 - Observationes in ordines plantarum naturales. Dissertatio II, sistens nuperas de Mucedinum et Gastromycorum ordinibus observationes. Der Gesellschaft naturforschender Freunde zu Berlin Magazin für die neuesten Entdeckungen in der gesammten Naturkunde 7, $25-45$.

MycoBank 2015 - MycoBank (Fungal databases nomenclature and species banks), accessed 1 February 2015. http://www.mycobank.org.

Sarbhoy AK, Agarwal DK, Varshney, JL. 1986 - Fungi of India (1977-1981). Associated Publishing Company, New Delhi. pp. 274. 
Sarbhoy AK, Agarwal DK, Varshney JL. 1996 - Fungi of India (1982-1992). CBS Publishers and Distributors, New Delhi. pp. 350.

Sarbhoy AK, Lal G, Varshney JL. 1975 - Fungi of India (revised) 1967-1971. Navyug Traders Bookseller \& Publishers, New Delhi. pp. 148.

Savile DBO. 1962 - Collection and care of botanical specimens. Canada Department of Agrriculture Publication Research Branch 1113. pp. 124.

Schubert K. 2005 - Morphotaxonomic revision of foliicolous Cladosporium species (hyphomycetes). Ph.D. dissertation. Martin-Luther-University Halle-Wittenberg, Germany, assessed 1 February 2015.

Singh R, Kumar S, Sharma P, Shukla K, Agarwal DK. 2008 - New taxa of Alternaria, Cladosporium and Corynespora from North-Eastern U.P. India. Indian Phytopathology 61(4), 504-509. 